\title{
Seasonal and interannual variations (1996-2000) of the coastal waters east of the Rhone river mouth as indicated by the SORCOM series
}

\section{Variations saisonnières et inter-annuelles (1996-2000) des eaux côtières à l'est de l'embouchure du Rhône suivies par la série SORCOM}

\author{
Walid A.N. Younes ${ }^{\mathrm{a}, \mathrm{b}}$, Nathaniel Bensoussan ${ }^{\mathrm{a}, *}$, Jean-Claude Romano ${ }^{\mathrm{a}, *}$, \\ Denise Arlhac ${ }^{\mathrm{a}}$, Michel-Guy Lafont ${ }^{\mathrm{c}}$ \\ ${ }^{a}$ UMR-CNRS 6540, Station Marine d'Endoume, 13007 Marseille, France \\ ${ }^{b}$ Department of Oceanography, Alexandria, Egypt \\ c UMS-CNRS 2196, Centre d'Océanologie de Marseille, Université de la Méditerranée, Marseille, France
}

Received 5 November 2001; received in revised form 12 June 2002; accepted 14 June 2002

\begin{abstract}
Between 1996 and 2000, 79 cruises have been achieved following always the same transect between Marseilles and the Rhone river's mouth. While cruising, salinity, temperature and fluorescence of surface waters $(1.5 \mathrm{~m})$ were recorded every minute, in association with precise GPS position. The whole set of data (i.e. 128 measured points per cruise) constitutes the Sorcom series whose synthetic results are presented here. Despite the high spatial and temporal variability encountered between two successive cruises, the regularity and duration of the sampling strategy permitted to define coherent spatial zonation and temporal evolutions. In the Cape Couronne vicinity the dynamic of the eastern extension of the dilution plume clearly changes. Westward, waters are frequently under its influence, but more sporadically to the east, with a less pronounced gradient. In few cases, salinity lowering has been measured up to the gulf of Marseilles. In these two areas, which can be divided in two sub zones, seasonal evolutions are different. In the eastern area (Cape Couronne-Marseilles), the classical rhythm prevailing over marine waters is observed but with earlier phytoplanktonic bloom than usually reported. In the western part, and as getting closer to the Rhone river mouth, a weaker seasonal variability is observed for the phytoplanktonic biomass then salinity and temperature differences remain high. The better knowledge of the eastern dilution plume is of important socio-economical concern due to the numerous population living on this coast and the presence of pollutants in the river waters.
\end{abstract}

(C) 2003 Éditions scientifiques et médicales Elsevier SAS and Ifremer/CNRS/IRD. All rights reserved.

\section{Résumé}

Entre 1996 et 2000, toujours selon le même trajet entre Marseille et l'embouchure du Rhône, soixante dix neuf missions ont été conduites. Le navire en route, toutes les minutes sont réalisées dans les eaux de surface $(1,5 \mathrm{~m})$ des mesures de salinité, température, fluorescence ainsi qu'un positionnement GPS. L'ensemble de ces données (soit 128 points de mesure par sortie) constitue la série Sorcom dont la synthèse de ces résultats est présentée ici. Malgré la forte variabilité spatiale et temporelle pouvant se manifester d'une sortie à l'autre, la stratégie de l'étude et sa durée permettent de dégager une zonation spatiale et des évolutions temporelles. C'est au voisinage du Cap couronne que se situe un changement net dans la dynamique d'extension, vers l'est, de l'influence du Rhône. A l'ouest, les eaux sont en quasi-permanence sous cette influence et plus sporadiquement vers l'est, avec un gradient moins marqué, mais dans certains cas une dessalure peut être détectée jusqu'à Marseille. Dans ces deux parties, chacune pouvant être découpée en deux sous zones, les évolutions saisonnières sont différentes. Si dans la partie est (cap Couronne-Marseille) on retrouve le rythme classique des eaux marines (avec une première poussée phytoplanctonique plus précoce que ce qui est reporté habituellement), la partie ouest (cap Couronne-Rhône) voit se mettre en place, au fur et à mesure que l'on se rapproche de l'embouchure, une plus faible variabilité inter saisonnière pour la biomasse phytoplanctonique alors que les écarts de salinité et surtout de température restent importants. La connaissance de la branche est de dilution des eaux du Rhône, sans doute moins étudiée car ne

* Corresponding authors. Fax: +33-4-91-04-16-35

E-mail addresses: bensoussan@com.univ-mrs.fr (N. Bensoussan),romano@com.univ-mrs.fr (J. Romano). 
correspondant pas à la direction privilégiée du panache, revêt une importance socio-économique particulière du fait de la population qui vit sur cette côte et de la présence, dans les eaux du fleuve, d'un cortège de polluants amenés par le drainage du bassin versant.

(C) 2003 Éditions scientifiques et médicales Elsevier SAS and Ifremer/CNRS/IRD. All rights reserved.

Keywords: Rhone river; Dilution plume; Long term observation; Fluorescence; Salinity

Mots clés : Rhône ; Panache de dilution ; Observation à long terme ; Fluorescence ; Salinité

\section{Introduction}

All the hydrosystems, which are located at the sea-land interface, such as estuaries, are well known to exhibit high levels of variability in space and time. At the lowest scale of variability, local weather conditions over determine the spreading direction of dilution plume and its extension in relation to the level of river outflow (Elliot and Hurford, 1989). Added to this first order of variability, the specific climatic rhythm prevailing over all the river basin and the own temporal dynamic of the sea water have significant consequences on the changes occurring in the composition of mixing zones (Rohling, 1994). At the highest investigated level of variability, global climatic oscillation (as example NAO, North Atlantic Oscillation) or long-time trends may introduce another order of variability. As a consequence of this mixture of climatic, hydrological and biogeochemical influences, the examination of such freshwater inflows in seawater and their consequences may constitute an interesting issue to study, and particularly when the river has a significant importance. Since the construction of Aswan dam in 1968 and the consecutive reduction of the Nile river inflows in the Mediterranean oriental basin, the Rhone river has become the most significant source of freshwater and particulate matter in the Mediterranean Sea with an average water discharge of $1700 \mathrm{~m}^{3} \mathrm{~s}^{-1}$ and a solid discharge of $6.2 \times$ $10^{6}$ t year $^{-1}$ (Dai et al., 1995; Martin and Saliot, 1991; Pont, 1992). Its potential influence, either positive by nutrients input (Coste and Raimbault, 1993) and enhancement of trophic resources, or negative (injection of pollutants, Lascombes, 1993; Unep, 1984) over the coastal waters depends of all the above-mentioned variability levels. In the past, numerous researches (Eros 2000 and Pnoc programs) have been conducted to study this influence. These works, often achieved by time-limited oceanographic cruises have mainly focused on the western part of the dilution plume which is the major direction of freshwater spreading, due to the drift induced by the North Mediterranean Current (Beckers et al., 1997; Millot, 1990). On the contrary, the eastern part of the Rhone river plume was less documented despite the fact that this direction of dilution may concern a coastal area with a population of more than one million of inhabitants. The knowledge at different scales of space and time of the eastern extension of the Rhone river plume is the main aim of the Sorcom series (Romano et al., 1999; Romano and Younes, in press; Younes et al., 1999), which are presented here. Since 1996, and as regularly as possible (on a fortnight basis), the same Marseilles-to-Rhone transect has been achieved, with continuous measurements (each minute, about 120 sets of measure by cruise) of some properties (temperature, salinity, fluorescence) of the surface seawater, with for each of them, a synchronized and precise GPS location which allows, from cruise-to-cruise, a comparisons of data collection. At the beginning of this long-time series, the selected frequency (every 2 weeks) was chosen in order to cover not only the seasonal time scale with a significant number of seasonal sampling but also the occurrences of some rare events such as time-limited but intense river flood (Pont, 1992). After 5 years of systematic examination of this same marine area and more than 80 cruises, the study presented here is the first attempt to synthesize this information at various scales of time and space.

\section{Material and methods}

Since 1996 and about each 2 weeks (depending on weather conditions), the same $30-\mathrm{km}$ there and back transit was achieved, from Marseilles to the Rhone's delta (Roustan buoy) where a CTD vertical profiling was achieved. Transect locations are presented in Fig. 1. The time departure was always the same (08:00 a.m.) and the operation was completed within 7-8 h, using always the same boat (O/V Antedon) cruising at the same speed (8.5-9 knots). This series of 88 cruises (between 1996 and 2000) was named Sorcom and is yet active. Only the complete transects $(n=79)$ and the journey there (Marseilles to the Rhone river) are considered here.

During the transit and at the cruising speed of the boat, the surface seawater (about $1.50 \mathrm{~m}$ depth) is continuously pumped with a flow rate of $11 \mathrm{~s}^{-1}$, through a hole of the hull, near the keel. The water is collected, in a 751 tank into which a "ME." (Meerestechnik Electronik GmbH, model ECO-57) multisensor probe is placed Fig. 2. Data acquisitions, of all sensor outputs (temperature, conductivity and fluorescence) are automatically recorded every 1 min by using a Portable Deck Unit (PDU 20).

Temperature, conductivity and fluorescence sensors are regularly controlled and calibrated by the manufacturer (three times in 5 years). In addition, seawater samples are collected at three stations during each transect Fig. 1), for further laboratory calibration and analysis. On this collected water samples, salinity measurements were performed on a Portasal salinometer, and pigment concentrations by HPLC assays on a $90 \%$-aceton extract after a GF/F-filtration of the 


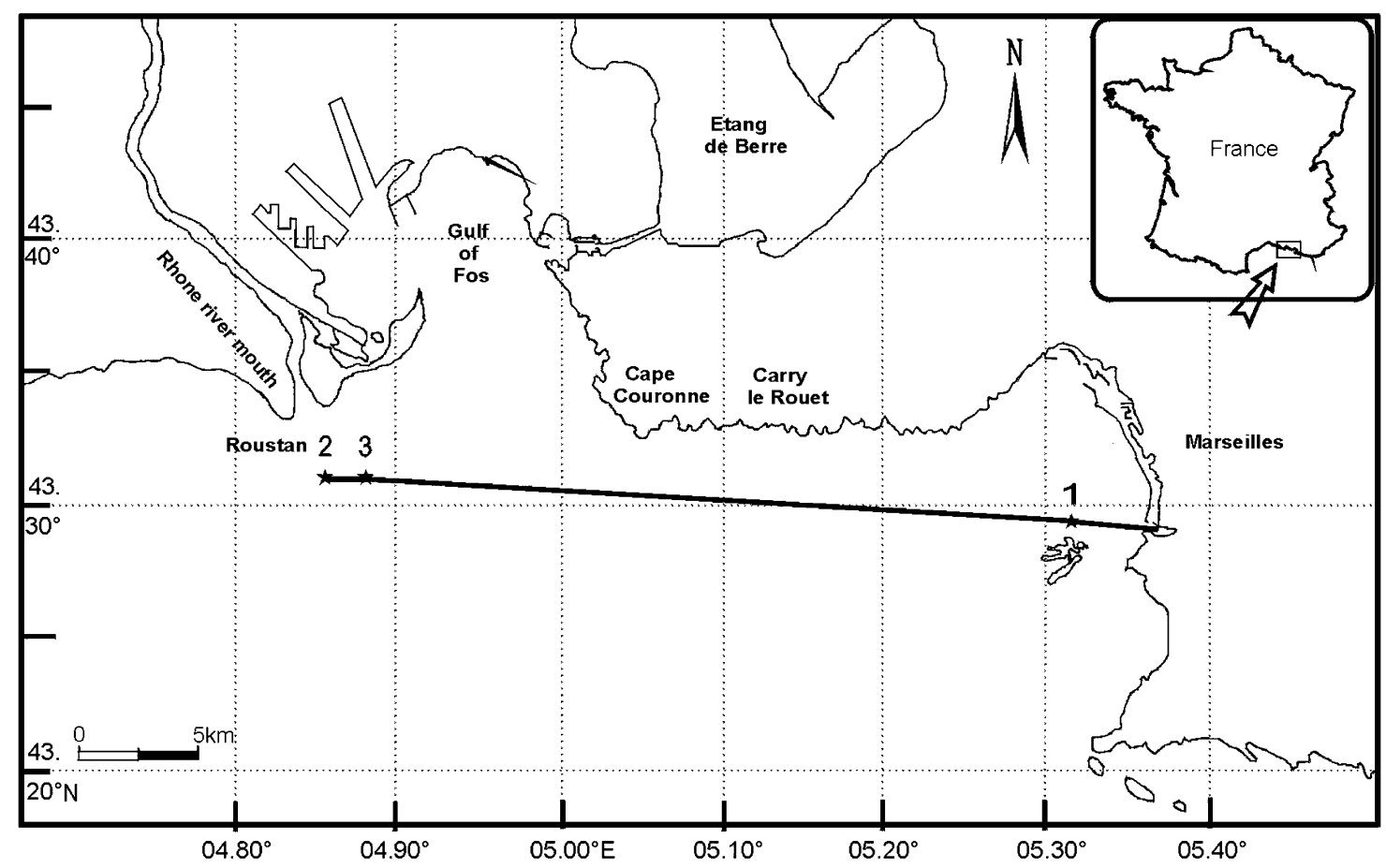

Fig. 1. Location map of the Sorcom transect between Marseilles and Roustan Buoy and position of the additional sampling stations (1-3).

particulate matter. When corrections are needed due to the occurrence of significant differences between sensor and laboratory measurements, the latter are considered as reference.

For a precise geographical position of each 1 min data acquisition in the surface seawater, PDU records are synchronized with a portable GPS device (MLR model Valsat P),

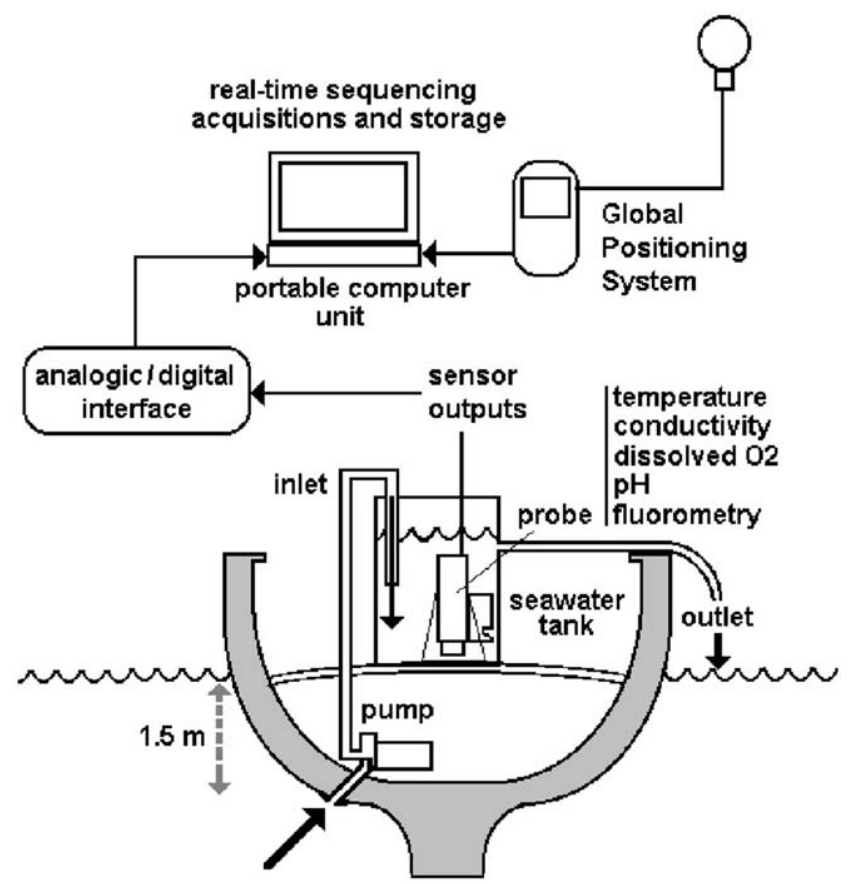

Fig. 2. Schematic representation of the system used for the continuous records of surface seawater characteristics at a $1 \mathrm{~min}$ interval, coupled with GPS acquisitions. fitted with an external antenna and following the same data storage frequency $\left(1 \mathrm{rec} . \mathrm{min}^{-1}\right)$. GPS data are transmitted (under RS-232 protocol) through the serial port of a computer in which they are treated and stocked in real time by using a special dedicated laboratory-made software. In order to control the boat way at real time, each GPS record was plotted at its real location on a chart on the computer screen.

Considering the regular cruise speed (8-9 knot) and the data record frequency (one per minute), with this nondifferential GPS device, the precision for geographical location ranges $\pm 30-50 \mathrm{~m}$, which is four to fivefold smaller than the average distance between two consecutive recording points (\#250 m). Moreover, since 2000, the precision of GPS signal was enhanced by reception of non-degraded satellite output as decided by US government.

The simple and low-cost system employed here (in-board pump, multiprobe and GPS location) is not permanently fixed on the O/V Antedon but installed for each cruise. In order to compare its records to those of a permanent on-line device, it was deployed on O/V Tethys II during the Sarhygol-7 cruise (April 2001) in the Golfe du Lion. On the 1733 data couples of salinity, temperature and fluorescence collected in sea-surface waters $(\# 1.5 \mathrm{~m})$ by the two systems, linear determination coefficients $\left(R^{2}\right)$ were as high as $0.98(P$ always inferior to 0.0001) and slopes closest to the unit for the three parameters respectively ranging 25-38 for salinity, 13.2-15.0 ${ }^{\circ} \mathrm{C}$ for temperature and 0.6-6.2 arbitrary fluorescence unit (afu) for fluorescence (unpublished data).

Both the sensors and GPS data files are gathered, cut in block containing 128 observations for each cruise from Marseilles to the Rhone and adjusted in position in order to 


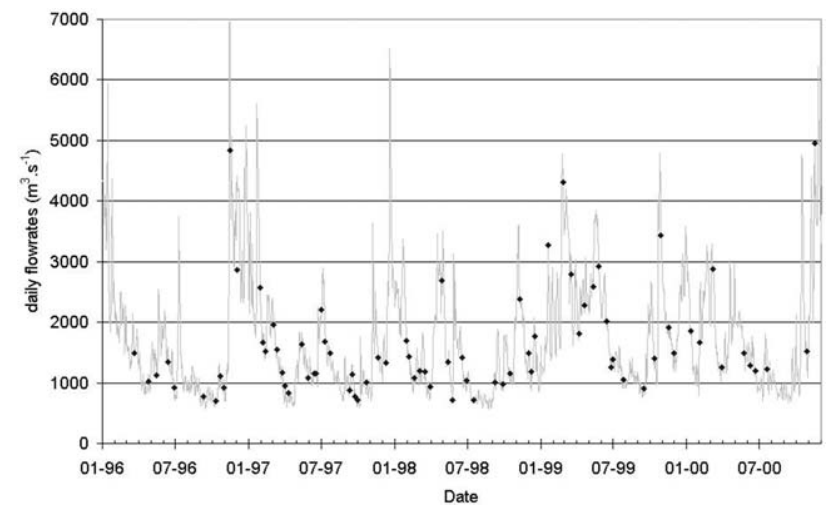

Fig. 3. Relative positions of Rhone river outflows corresponding with each Sorcom cruise (dot) inside the whole daily outflow evolution since 19962000 (line).

perform further valuable comparison on a precise geographical basis. Considering the way of Sorcom cruises, which is roughly parallel to $43.30^{\circ}$, the weak differences (average $<0.6$ nautical mile) in latitude along the transit are not considered in this paper as significant.

All the cruises were performed under wind-speed conditions lower than $6 \mathrm{~m} \mathrm{~s}^{-1}$. Taking into account the limitations by bad-weather conditions and logistic constraints, the effective average periodicity of the Sorcom series, over the 5 years of activity, is $20.7 \mathrm{~d}$ as a mean. On a seasonal basis (solstice and equinox date $(21 / 03,21 / 06,21 / 09,21 / 12)), 25$ cruises were performed in spring, 15 in summer, 23 in autumn and 16 in winter. As compared to the variability of the Rhone river outflow, the representativity of the Sorcom series is discussed in the Result section. Other technical reports about the Sorcom series are extensively developed in Younes (2000).

Some different databases were used here. Distributions of Rhone river daily and monthly averaged outflows recorded at Beaucaire are available by Minitel (3617-Inforhone), river monthly temperature from 1986 to 1997 at Beaucaire (Agence de l'Eau-RMC web site: http://www.rdb.eaurmc.fr), coastal sea surface temperature, either from Marseilles's maregraph (1993-1996) or Capcom series (1996-1999), both being available on the web site of the "Service d'Observation du Centre d'Océanologie de Marseille" (http://www.com.univ-mrs.fr/SLT/) and meteorological data from Meteo-France (Minitel-meteo access code).

The whole set of data of the Sorcom series (temperature, salinity, fluorescence measurements and their relative location) can be extensively consulted, date by date, for raw data and graphics, on the web site http://www.com.univmrs.fr/SLT.

\section{Results}

\subsection{Rhone river flow and sampling representativity}

In Fig. 3 are plotted the daily outflows of the Rhone river as recorded at Beaucaire since January 1996 to December 2000 (line) and the respective values which correspond to the

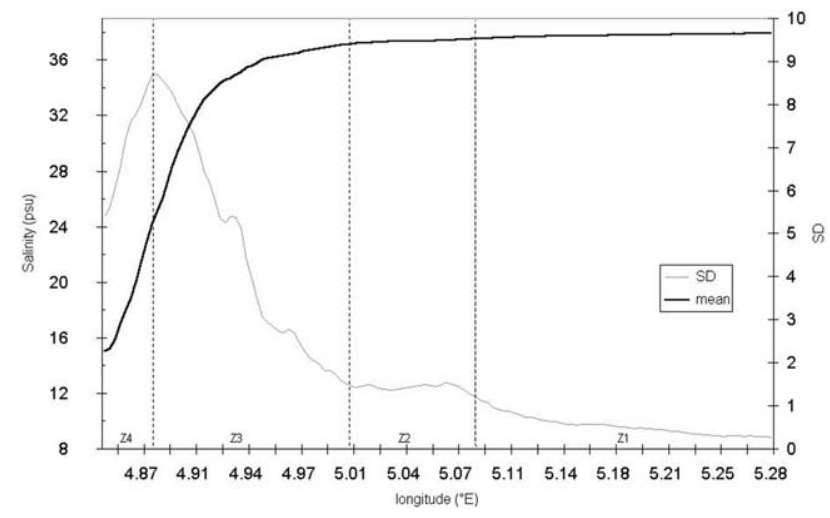

Fig. 4. Evolution of salinity mean and dispersion (S.D.) along the Sorcom transit between 4.85 and $5.28^{\circ} \mathrm{E}$ over the 79 cruises (1996-2000).

Sorcom-cruise dates (point). All over the 1996-2000 period, the daily Rhone outflows varied from 570 to a maximum of $6977 \mathrm{~m}^{3} \mathrm{~s}^{-1}$ (14/11/2000 flood), with an average value of $1745 \pm 960 \mathrm{~m}^{3} \mathrm{~s}^{-1}$. The Sorcom-cruises corresponding outflows ranged from 707 to $4997 \mathrm{~m}^{3} \mathrm{~s}^{-1}$ with an average of $1639 \pm 889 \mathrm{~m}^{3} \mathrm{~s}^{-1}$, a value which is close to the previous, but with an under-representation of the extrema reflecting both the bad-weather (winter) or logistic (summer) limitations of the Sorcom series.

The daily registered river outflows which are higher than $4997 \mathrm{~m}^{3} \mathrm{~s}^{-1}$ and lower than $707 \mathrm{~m}^{3} \mathrm{~s}^{-1}$ represent no more than $0.7 \%$ and $3.8 \%$, respectively, of the situations. If we consider the respective positions of points and line in Fig. 3 . we may consider that the periodicity of the Sorcom series provides a representative sampling of the river outflow variability. But as it appears in the figure, some outflows of short duration may not be sampled.

Another bias must be considered from a meteorological point of view. In this Mediterranean coastal area, wind speed higher than $6 \mathrm{~m} \mathrm{~s}^{-1}$ (the upper limit for Sorcom cruises) may represent a percentage ranging from $20 \%$ to $30 \%$ of the annual records (Meteo-France and COM databases; Younes, 2000). This constitutes a serious limit of the Sorcom data in order to understand the dynamic of the Rhone river freshwater spreading at the surface of eastern marine coastal waters.

\subsection{Variability of salinity data along the transect}

In Fig. 4 are plotted the mean salinity and dispersion (standard deviation, SD) values $(n=128)$ as they were registered over the 5 years of experiment. Each plotted point represents the mean or dispersion, at the same geographical location, of all the salinity measurements recorded during the 79 cruises. From east to west, the salinity remains stable for the first half of the transect and then regularly decreases in parallel to an enhancement of the dispersion. Despite the fact that this graphic includes a wide time duration (5 years and 79 cruises) with seasonal rhythm and some strong flood events, the highest variability in salinity distribution which is recorded about 2 miles on the east of the mouth, is of the 
Table 1

Zonal descriptive statistics of the surface water salinity recorded during the 79 Sorcom transects

\begin{tabular}{lllll}
\hline & $\mathrm{z} 1$ & $\mathrm{z} 2$ & $\mathrm{z} 3$ & $\mathrm{z}$ \\
\cline { 2 - 4 } Longitude $\left({ }^{\circ}\right)$ & $5.280-5.092$ & $5.088-5.004$ & $3.0001-4.880$ \\
\hline Mean & 37.777 & 37.341 & 33.466 & 0.666 \\
Standard error & 0.013 & 0.021 & 4.049 & 0.828 \\
S.D. & 0.095 & 0.111 & 22.904 & 2.341 \\
Minimum & 37.554 & 37.082 & 37.019 & 15.041 \\
Maximum & 37.909 & 37.534 & 37 & 21.498
\end{tabular}

Comparison between groups

\begin{tabular}{llll} 
& $\mathrm{z} 1$ to $\mathrm{z} 2$ & $\mathrm{z} 2$ to $\mathrm{z} 3$ & $\mathrm{z} 3$ to $\mathrm{z} 4$ \\
\hline$Z$ & 17.484 & 5.819 & 14.854 \\
$P(Z \leq z)$ two-tail & $2.00 \mathrm{E}-21$ & $1.82 \mathrm{E}-09$ & $3.62 \mathrm{E}-11$ \\
$z$ critical two-tail & 1.645 & 1.645 & 1.645
\end{tabular}

same order of magnitude $( \pm 5)$ as the difference in salinity between the marine waters located near Marseilles (up to 37.8) and the brackish waters (\#15) encountered in front of the Rhone.

A detailed examination of the dispersion trend along the transects, indicates that from Marseilles to Cape Couronne (\#5.00 in longitude), all the S.D. values are lower than 2.0 but in two sections: lower than $1.0(\mathrm{z} 1 ; m=0.53 ; n=56)$ before Carry-le-Rouet and twice this value after $(\mathrm{z} 2 ; m=$ $1.43 ; n=27)$. Then they rise to a maximum (9.0), at a point located about 2 miles on the east of the Rhone mouth (z3; $m=4.90 ; n=37$ ) and then regularly decrease to a value of 5.0 at the western end point of the transect (Roustan buoy) which is located in front of the Rhone river mouth.

When this distribution is compared to the corresponding mean salinity values, it is possible to define four zones Table 1, where surface-water salinity is regularly decreasing from east to west (respectively, 37.777 to 17.687 for $z 1$ to z4). Inside each of these four zones, examinations of descriptive statistics Table 1 show that they are coherent: SD values are always significantly lower than their respective mean value (normal distributions) and extrema found in all the zones appear to be in conformity with our previous knowledge and literature. Moreover when the means of two adjacent groups are compared by a $z$-test, they also appear to be significantly different Table 1 .

\subsection{Variability of the eastern limit of brackish waters}

In the same area (Gulf of Marseilles), and covering the same time period (1994-2000), salinity records collected in a place located out of any freshwater influence displayed surface salinity values ranging from 37.67 to 38.12 (see database http://www.com.univ-mrs.fr/slt/). In literature, the lower salinity limit is classically considered as 37.5 for strictly marine coastal waters in the same area. Cautionary, we have considered the 37.3 value as the threshold between, on one side the typical Mediterranean marine waters of this coastal area exhibiting higher salinity values, and, on the other side, the appearance of a freshwater influence. Over the 79 examined cruises, this value was researched and occur- rences were classed in $0.005^{\circ}$ longitude intervals, in order to constitute a frequency distribution of this limit along the transect. In Fig. 5 we present the cumulative relative frequencies of the 37.3 isohaline position along the Sorcom transect. At the beginning of the Sorcom transect, salinity is always higher than 37.3 , but rapidly the frequency of situations where the salinity is superior to 37.3 psu regularly decreases to the west. Little after Cape Couronne $\left(5.010^{\circ} \mathrm{E}\right)$, the slope of this trend abruptly changes with a more rapid fall. The median position where brackish water can be detected is $4.949^{\circ} \mathrm{E}$ (in front of the They-de-la Gracieuse). Westward and till the close vicinity of the Roustan buoy $\left(4.850^{\circ} \mathrm{E}\right)$, this frequency is never null.

We have translated this relative frequency distribution in an occurrence probability to find a significant freshwater influence in the coastal marine waters located east off the Rhone. In Fig. 6 as a function of geographic location, we have compared the distribution of the measured data points (situations where salinity value is under the 37.3 threshold) and adjustment models either for the whole set of data or for the two parts of the Sorcom transit located on each side of $5.010^{\circ} \mathrm{E}$. If all the set of data is considered, the best fit is adjusted to a polynomial model $\left(R^{2}=0.991 ; n=128 ; P<\right.$ $0.0001)$. Which must be considered as realistic for dilution

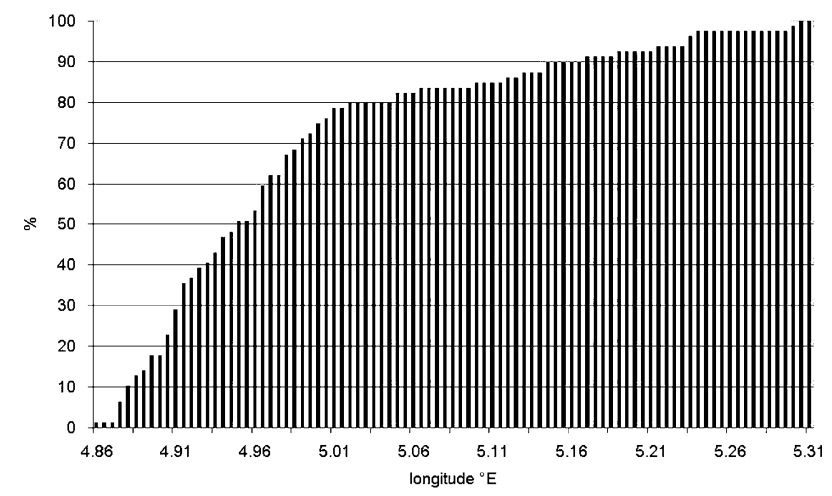

Fig. 5. Cumulative relative frequency distribution of the 37.3 isohaline position along the Sorcom transect over the 79 cruises (1996-2000). The measuring points were grouped considering $920.005^{\circ}$ intervals between 4.850 and $5.310^{\circ} \mathrm{E}$. 


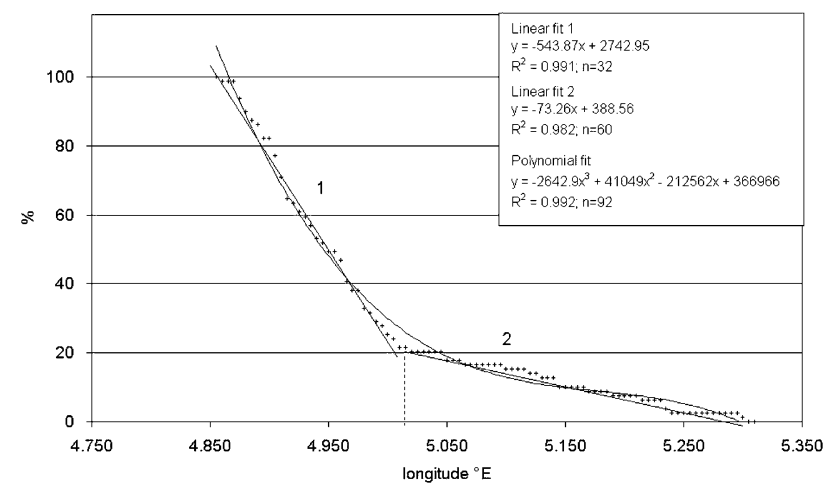

Fig. 6. Relative distribution frequency of Rhone's dilution plume extent along the Sorcom transit over the 79 cruises (1996-2000) based on a 37.3 psu criteria. Polynomial and linear fits in caption.

processes of freshwaters in marine ones. In fact, and taking into account the significant number of values, we have tried to describe the two parts of the dilution plume dynamics, each of them by a linear adjustments with significantly different $a$-slopes: for the west part of the transit (linear fit 1), $a=-543.87\left(R^{2}=0.991 ; n=32 ; P<0.0001\right)$ and for the east part (linear fit 2) $a=-73.26\left(R^{2}=0.982 ; n=60 ; P<0.0001\right)$. These two different slopes provide evidence for significant change in dilution dynamic of the Rhone river at the surface of coastal waters. The intersection of the two lines gives a realistic estimation $\left(5.003^{\circ} \mathrm{E}\right)$ for the longitude position of the mixing point between the water masses, on one side mainly influenced by dilution plume, and on the other only occasionally.

\subsection{Evolution of fluorescence records along the Sorcom transect}

Mean fluorescence values and their statistical framework ( $m \pm \mathrm{SD}$ ) were calculated, point-by-point, over the 79 cruises and are presented in Fig. 7. The mean plot exhibits a regular increase from the marine coastal waters located near Marseilles to the Roustan buoy, where the fluorescence values reach their average upper limit. But all over the sampling period (1996-2000), the dispersion is considerably higher than that of salinity distribution (Fig. 4) as attested by the

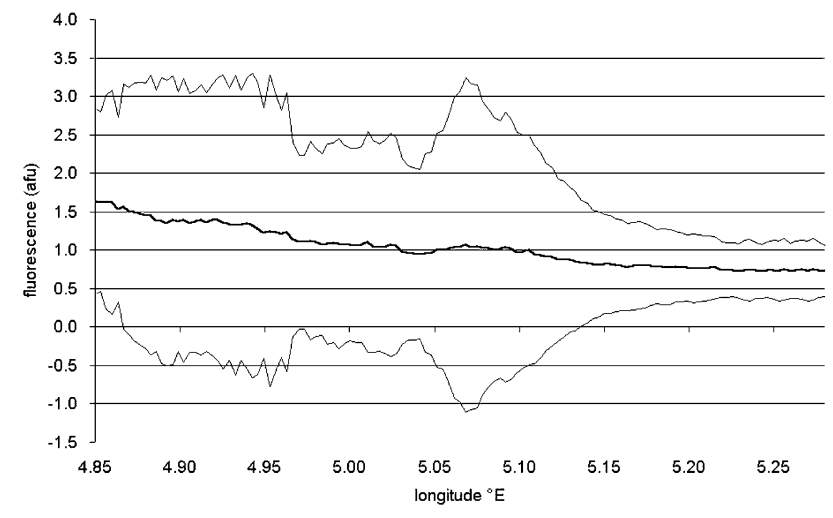

Fig. 7. Evolution of fluorescence mean and dispersion ( $m \pm$ S.D.) along the Sorcom transit between 4.85 and $5.28^{\circ} \mathrm{E}$ over the 79 cruises (1996-2000).

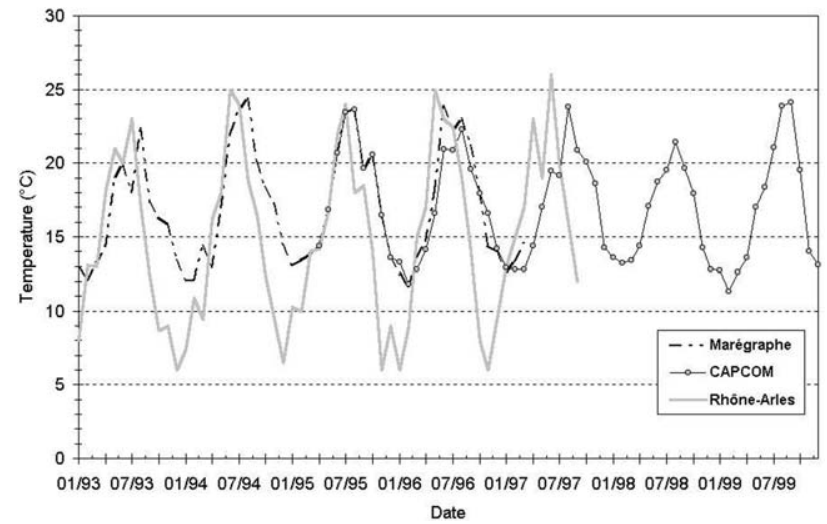

Fig. 8. Annual thermal cycles of Rhone's freshwaters measured at Arles (1993-1996) and of the coastal surface marine waters in the Gulf of Marseilles for the years 1993-1999 (Maregraph and Capcom series).

trends of $m \pm$ SD curves (the negative $m-$ S.D. values express only the statistical dispersion, not the output reading of the fluorometer). The coastal waters located between Carry-leRouet and Cape Couronne $\left(5.05-5.15^{\circ} \mathrm{E}\right)$, show a large dispersion peak but without any significant correspondence in salinity profiles Fig. 4. A short lowering of these dispersion plots is noted front of the gulf of Fos, and then all the area located around the Rhone river mouth remains always highly variable. It appears clearly that this rough and global treatment of the fluorescence records may mask various underlevels of variability, induced either by seasonal fluctuations or time-limited events such as floods or local phytoplanktonic blooms (less than a week) as previously reported in Younes (2000). The fact to detect these time limited events may constitute a validation of the Sorcom strategy with its based on 2 weeks periodicity.

\subsection{Seasonal variations of temperature and salinity}

Based on monthly average, the respective annual temperature cycle of the Rhone river (unfortunately the Rhone temperature series has been stopped in 1998) and the marine coastal waters (a compilation of Maregraph and Capcom series - see data-bank address in Material and methods) are presented in Fig. 8. Two elements may have some consequences upon the mixing dynamic of these waters. The first is the width of the variations range: monthly averaged freshwater temperatures may vary from 6 to $7^{\circ} \mathrm{C}$ in winter to more than $25^{\circ} \mathrm{C}$ in summer whereas surface coastal marine waters never overpassed $24^{\circ} \mathrm{C}$ in summer or never decreased below $11{ }^{\circ} \mathrm{C}$ in winter. The second difference is the time shift registered for these limits: the freshwaters reach their extrema about $40 \mathrm{~d}$ before the marine waters.

Both salinity and temperature records of the 79 cruises are clustered on a seasonal basis and the mean $T-S$ relationships are examined and compared for each of the 128 averaged values along the transit from Marseilles to the Rhone. These seasonal diagrams are plotted in Fig. 9.

During the winter period (21 December to $21 \mathrm{March}$ ) the colder $\left(9-10{ }^{\circ} \mathrm{C}\right)$ brackish waters $(12-13 \mathrm{psu})$ were progres- 


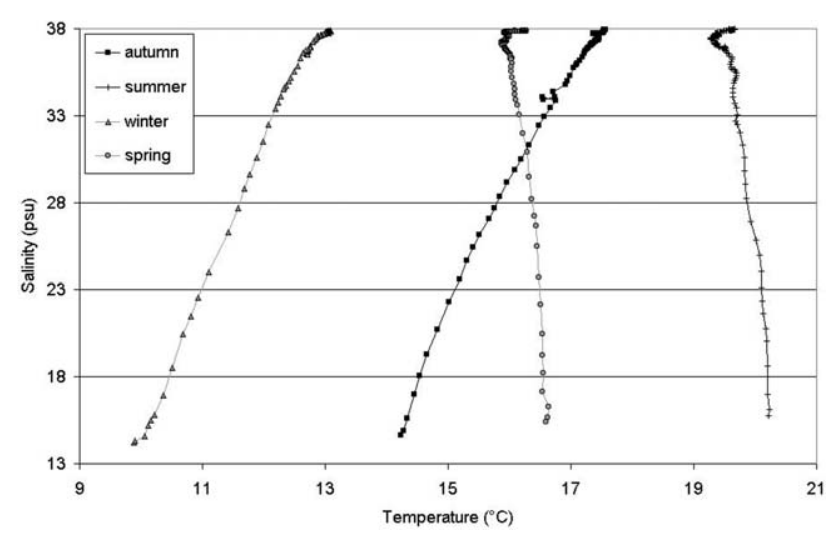

Fig. 9. Mean seasonal temperature-salinity relationship for the surface waters along the Sorcom transit. Each plotted point corresponds to the average temperature and salinity calculated at the same position over 23 cruises in autumn, 15 in summer, 16 in winter and 25 in spring.

sively replaced from west to east by coastal marine waters (38.0), which never overpassed $14{ }^{\circ} \mathrm{C}$. The linear $T-S$ relationship is highly significant at $P 0.001$ level $\left(n=128 ; R^{2}=\right.$ 0.985). In autumn (21 September to 21 December), a parallel evolution, as highly significant as winter situation, is noted (Fig. 9), but with globally higher surface temperature all along the transit (about $4-5^{\circ} \mathrm{C}$ ).

On the other hand, during spring (21 March to 21 June) and summer (21 June to 21 September), the $T-S$ diagrams show opposite trends to the previous ones: the seasonally averaged temperatures are regularly decreasing when the salinity is increasing. The spring and summer relationships are also significant at $P 0.001$ levels, but slopes are inverted and, particularly for summer time, weaker than winter and autumnal lines. In fact, when a typically summer cruise is solely considered $(22 / 07 / 1997$ or $16 / 07 / 1998$, see Younes, 2000), the slope values of the $T-S$ linear fit are always inverted but as high as those recorded for the averaged winter diagram. This is, in part, a consequence of the less-fair representativity of the summer period in Sorcom series, as it was above mentioned: for logistic reasons (holidays of the crew) most of the summer cruises have been conducted in the first part of the season, when the freshwater temperatures had not reached their maximal values. Another observation concerns the high-level of variability prevailing during summer period and in marine waters, due to the strong but timelimited influence of meteorological conditions. During this season, the occurrence of north-westerly wind events and their cooling consequences on surface waters by up-welling of deeper and colder waters, are attested by the wider range of variations (Fig. 10) recorded in marine waters (salinity > 37.5).

\subsection{Seasonal and zonal variations of fluorescence data}

In Table 2 are presented fluorescence data averaged by season and grouped following the four different zones as above-defined (see Table 1. In zone 1 (typical marine waters), the highest fluorescence mean values were recorded in

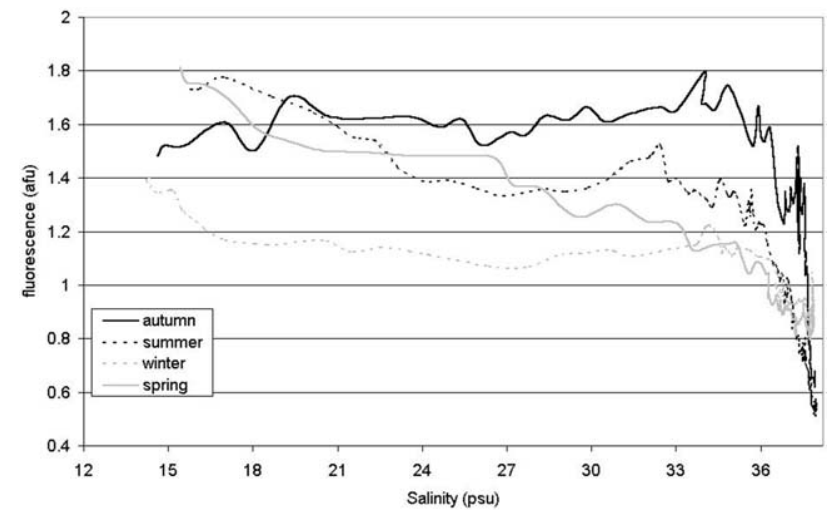

Fig. 10. Mean seasonal fluorescence-salinity relationship for the surface waters along the Sorcom transit. Each plotted point corresponds to the average salinity and fluorescence calculated at the same position over 23 cruises in autumn, 15 in summer, 16 in winter and 25 in spring.

winter $(0.911 \pm 0.044 \mathrm{afu})$ and autumn $(0.863 \pm 0.219 \mathrm{afu})$ and with a higher variability for the latter, and the lowest mean values in summer $(0.621 \pm 0.083 \mathrm{afu})$.

On the opposite, inside the area permanently influenced by the Rhone river (zone 4), mean values are the highest as compared to the two other zones and they exhibit few differences between autumn, summer and spring (1.574, 1.661 and $1.640 \mathrm{afu}$, respectively) but significant lower value in winter $(1.293 \pm 0.096 \mathrm{afu})$. From east to west ( $\mathrm{z} 1$ to $\mathrm{z} 4)$, the relative importance of winter in phytoplanktonic-biomass annual budget appears to be progressively weaker and, on the opposite, higher for autumn and summer. These zonal and seasonal distributions of phytoplanktonic-population size provide evidence for strong relationships with salinity trends.

\subsection{Salinity-fluorescence relationships}

In Fig. 10 are presented for each season, the seasonal mean fluorescence values as a function of salinity for each of the measuring points of the Sorcom transits. These plots clearly exhibit two trends along the salinity axis, with different salinity-fluorescence ratios. From the lower mean salinity values to 33 , for all the seasons, fluorescence records are higher than in marine waters, but exhibit a relatively lower dispersion inside the same season. On the opposite, the fluorescence values exhibit a higher level of dispersion, even in the same seasonal period, ranging from 0.5 to 1.8 afu for salinity values $>33$. For the brackish waters with salinity $\leq 33$, all the relationships are negative (excepted in autumn) and statistically significant Table $3 R^{2} \geq 0.619$ for $n=16-22$; $P<0.001)$.

Fluorescence data exhibit their relative lowest values during winter $(1.18 \pm 0.09, n=29)$, and the highest during autumn $(1.52 \pm 0.07, n=32)$. During spring and summer, the data are generally plotted between the two other curves and present strong correlation with salinity Table 3. On the other hand, above the 33 salinity threshold, various wide ranges of fluorescence values are associated to relatively narrow salinity dispersion and with higher slope values than 
Table 2

Zonal (as defined in Table 1) and seasonal descriptive statistics of the surface fluorescence data recorded during the Sorcom transects

\begin{tabular}{|c|c|c|c|c|}
\hline & \multicolumn{4}{|c|}{ Fluorescence (afu) } \\
\hline & Autumn & Winter & Spring & Summer \\
\hline \multicolumn{5}{|c|}{ Zone $1(n=56)$} \\
\hline Mean & 0.863 & 0.911 & 0.838 & 0.621 \\
\hline S.D. & 0.219 & 0.044 & 0.027 & 0.083 \\
\hline Minimum & 0.620 & 0.842 & 0.795 & 0.511 \\
\hline Maximum & 1.397 & 1.046 & 0.912 & 0.801 \\
\hline \multicolumn{5}{|c|}{ Zone $2(n=27)$} \\
\hline Mean & 1.334 & 0.884 & 0.864 & 0.898 \\
\hline S.D. & 0.116 & 0.040 & 0.030 & 0.098 \\
\hline Minimum & 1.118 & 0.818 & 0.813 & 0.739 \\
\hline Maximum & 1.518 & 0.951 & 0.927 & 1.039 \\
\hline \multicolumn{5}{|c|}{ Zone $3(n=37)$} \\
\hline Mean & 1.555 & 1.066 & 1.092 & 1.311 \\
\hline S.D. & 0.159 & 0.086 & 0.181 & 0.113 \\
\hline Minimum & 1.231 & 0.923 & 0.889 & 1.051 \\
\hline Maximum & 1.794 & 1.220 & 1.483 & 1.522 \\
\hline \multicolumn{5}{|c|}{ Zone $4(n=8)$} \\
\hline Mean & 1.574 & 1.293 & 1.640 & 1.661 \\
\hline S.D. & 0.078 & 0.096 & 0.126 & 0.089 \\
\hline Minimum & 1.481 & 1.150 & 1.495 & 1.537 \\
\hline Maximum & 1.702 & 1.401 & 1.811 & 1.775 \\
\hline
\end{tabular}

for the first group. The four seasonal relationships are also significant at $P 0.001$ level $(n \geq 106)$ and presented in Table 3 The summer and fall fluorescence values are dispatched inside a wider range of variation than those related to winter and spring.

\subsection{Yearly variability of salinity profiles in relation to Rhone river outflows}

The Sorcom series (yet active) has covered only 5 years but we have considered that we had just enough data to make an interannual comparison of the annual outflow levels of the Rhone river and their consequences on the eastward extension of the dilution plume. The results presented in Fig. 3 are a good index to consider that the Sorcom sampling strategy is representative of the Rhone outflows variability. They were here completed Fig. 11) by the relationship, on a monthly averaged basis, of both the whole monthly records of the river outflows at Beaucaire and those recorded the days of Sorcom cruises for the same month. As attested by the regression line $\left(R^{2}=0.675 ; n=49 ; P<0.001\right)$, it may be considered that the adequation between the two set of data is correct even if the divergence becomes wider when the river flow increases (>1500 $\mathrm{m}^{3} \mathrm{~s}^{-1}$-flood events). It was necessary to assess that the Sorcom cruises had been conducted under representative Rhone outflow conditions before trying any interannual comparison.

We present in Fig. 12 the annual mean salinity value, as calculated for each of the 128 points of the Sorcom transect since 1996-2000, and, in the legend, the respective annual

Table 3

Seasonal regression statistics between mean fluorescence-salinity records during the Sorcom transects

\begin{tabular}{|c|c|c|c|c|}
\hline & Autumn & Summer & Winter & Spring \\
\hline \multicolumn{5}{|c|}{ Salinity criteria $<33$} \\
\hline$R^{2}$ & 0.295 & 0.619 & 0.659 & 0.915 \\
\hline$a$ & 0.005 & -0.020 & -0.014 & -0.030 \\
\hline$b$ & 1.465 & 1.997 & 1.493 & 2.194 \\
\hline$n$ & 21 & 22 & 19 & 16 \\
\hline \multicolumn{5}{|c|}{ Salinity criteria $>33$} \\
\hline$R^{2}$ & 0.566 & 0.872 & 0.720 & 0.877 \\
\hline$a$ & -0.263 & -0.241 & -0.074 & -0.090 \\
\hline$b$ & 10.894 & 9.758 & 3.706 & 4.217 \\
\hline$n$ & 107 & 106 & 109 & 112 \\
\hline
\end{tabular}




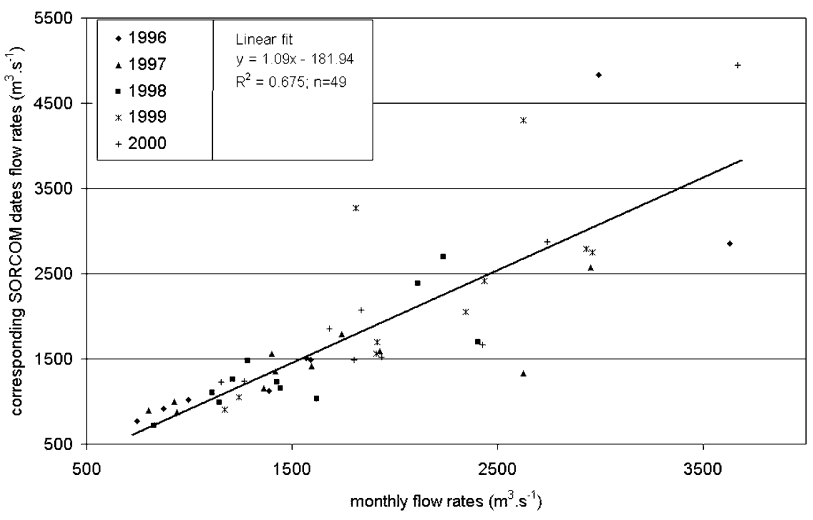

Fig. 11. Relation on a monthly averaged basis between Rhone river monthly records of the river outflows at Beaucaire ( $X$ axis) and those recorded the days of Sorcom cruises for the same month ( $Y$ axis).

mean value of the Rhone outflows. The vertical lines correspond to the limits between the four zones as they are defined in Table 1 For the two eastern $\mathrm{z} 1$ and z2 zones (marine waters dominance with salinity ranging from 36.7 to 38.2 ) the interannual differences are weak. But, at the beginning of zone z3, a significant difference appears in salinity profiles of 1999 and 2000, i.e. the years with the highest river outflows (2177 and $2018 \mathrm{~m}^{3} \mathrm{~s}^{-1}$, respectively). At this location and for these 2 years, the salinity decrease is more pronounced compared to the other profiles and salinity reaches its relative lowest level. This salinity shift tends to diminish westward but is maintained till the end of the transect, in front of the Rhone. On the opposite, the 1998 curve, associated to the lowest annual outflow $\left(1338 \mathrm{~m}^{3} \mathrm{~s}^{-1}\right)$ presents the highest average salinity profile.

\section{Discussion and conclusions}

It was a great deal to try to synthesis 5 years of study of such a highly changing marine environment as an estuarinemarine area is. Most of the previously published papers upon the influence on Rhone river to the surrounding coastal waters have strongly pointed out the over determination of local

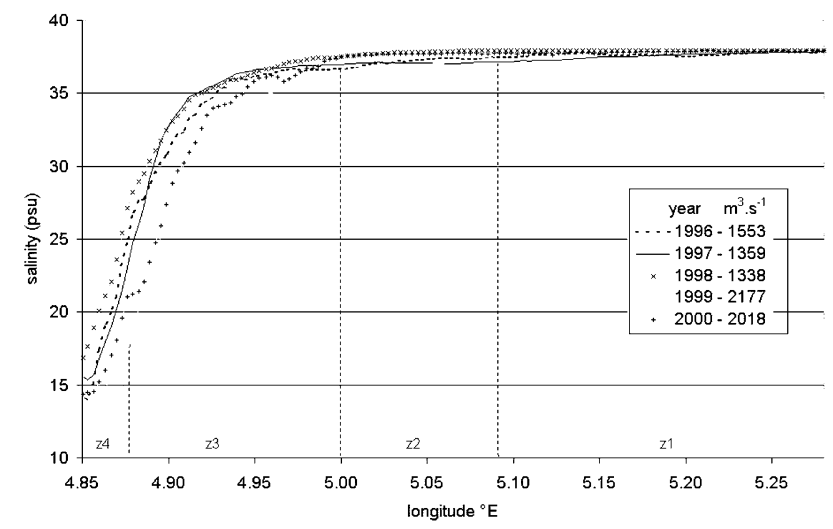

Fig. 12. 1996-2000 annual average salinity evolution along the Sorcom transect and corresponding Rhone river annual mean outflow calculated on the basis of cruises dates (in caption). conditions on the spreading dynamic of the freshwaters. Rapid changes in the eastern extension of the dilution plume have also been recorded by Sorcom series, not only from cruise to cruise but sometimes during the same cruise, between the transits there and back (Younes, 2000). All these levels of variability in space and time cannot be resumed by the dispersion curve of salinity values presented in Fig. 4. But, on the other hand, the results presented here allow us to discriminate several general trends.

The first is the presence, most of the time, of brackish surface waters on the east of the Rhone river mouth and in the gulf of Fos, the less-studied component of the dilution plume. The second is the possibility, despite the high variability of the system, to describe this complex mixing area by the definition of some zones which are statistically coherent, not only on a space basis considering the Rhone river as the most important signal but also at various time scales.

As attested by the reported frequency distribution of the 37.3 isohaline Fig. 5, this influence may in more than 20\% of the cases reach the marine area located off Cape Couronne. In some rare cases $(<5 \%)$ a freshwater influence can be detected as far as the vicinity of Marseilles. But the dilution plume extension in the east direction, appears to follow significantly different dynamics Fig. 6 when either the situation on the east or on the west of $5.010^{\circ} \mathrm{E}$ (vicinity of Cape Couronne) are considered. When a yearly comparison is conducted Fig. 12), between, on one side, the Rhone river outflow values and, on the other side, the signature and extension of eastern dilution plume, the consequence seems not to be a clear eastern drift of the brackish-water limit (37.3 value), but a global decrease of the annually averaged salinity of the waters located on the west of Cape Couronne. The comparison of both averaged salinity and fluorescence evolutions along the transect Figs. 4 and 7) provides evidence for different Rhone river influence upon these two parameters. The salinity curve Fig. 4 exhibits a regular trend, with, front of the gulf of Fos-sur-Mer, only a light but significant mark in the distribution curve (SD) whereas, as exposed in Fig. 7, a strong variability in the fluorescence values appeared at the same geographical location. This is relevant to the occurrence of some events (as example-30/09/1997; see Younes, 2000) which have been registered during the Sorcom series and where pigment concentrations were enhanced by a factor 10 , from a week to another, then decreased to previous normal values in some days, but sometimes without any correspondence in salinity lowering. In these cases, local phytoplanktonic bloom can be supposed.

On the opposite, in the waters located under the direct influence of the Rhone river, strong relationships always exist between salinity and fluorescence value. As other rivers, Rhone inflows contributes not only to nutrient but also to important particulate organic load and phytoplanktonic input (Lochet and Leveau, 1990; Loeillet and Leveau, 1985; Cauwet et al., 1990). And the fact that the phytoplanktonic biomass (chl.a equivalent and cell counts) living in freshwaters is currently as high as 10 -fold the one present in Medi- 
terranean marine waters is of importance. So if salinity decrease and fluorescence increase are generally closely associated in the marine area located near the Rhone estuary, significant enhancement in phytoplanktonic biomass may also happen under the influence of other water sources (gulf of Fos, exit of Etang-de-Berre waters through Caronte channel). We can note that averaged fluorescence maxima and minima recorded in surface waters Table 2 are different in the first two zones ( $\mathrm{z} 1$ and $\mathrm{z} 2$ ) as compared to $\mathrm{z} 3$ and $\mathrm{z} 4$ where the waters are more-permanently influenced by Rhone river outflows and their inputs of particulate matter and phytoplanktonic biomass. Front of the Rhone it was also noted that winter is not the time-period exhibiting the highest fluorescence values, but summer, result which is different to the fluorescence dynamic in marine waters.

In literature it is classically considered that the "normal" evolution of the phytoplanktonic biomass at the front of dilution plume is characterized by spring bloom occurring in April with a mean duration of 5-6 weeks (Conan et al., 1998; Lefevre et al., 1997), and which are triggered by temperature increase and stratification of the water column, together with an increase of the photoperiod. Minor blooms may appear in summer and autumn as the consequence of up-welling process (Millot, 1979) and nutrient enrichment by the Rhone. On the other hand, by an examination of large-scale Sea-Wifs views of the Mediterranean north-occidental basin, Barale (1999) arises to the same conclusions. By the study of monthly satellite views arranged in time-sequence, Barale and Zin (1997) have noted that the dynamic of surface water color and temperature are different in typical marine areas and in the coastal waters influenced by river inflows. In the latter situations, during the first part of the year, these authors have noted both a pigment-concentration increasing gradient and temperature decreasing from open sea to the coasts and, on the opposite, a reverse evolution in the second part of the year and they concluded to the difficulty to separate time and space dynamic in these complex environments.

From the synthetic results presented here, the seasonal variations recorded front and east of the Rhone river mouth are complex but may be resumed as follows.

Front of the Rhone, the phytoplanktonic biomass always exhibits high levels, without a direct or clear relation to the outflows values of the river. A high $\mathrm{chl} \mathrm{a} / \mathrm{chl} \mathrm{b}$ ratio (in sediments as in surface waters-Younes, 2000; Alliot et al., in press) provides evidence for its freshwater origin. The significantly lower fluorescence values recorded in winter, associated to low salinity and high outflow values, is probably not only the consequence of lower production of the freshwaters, but also the result of a dilution of the phytoplanktonic cells in the high loads of particulate matter transported by the river at this season. As for particulate organic matter (Eisma et al., 1985), the importance of this continental contribution to global fluorescence is progressively decreasing eastward, from estuary to the sea, and a seasonal dynamic begins to appear through the zone 3 and zone 2 evolution Table 2, with, sometimes, the occurrence of time-limited phytoplanktonic blooms in this mixing zone. In the typical marine waters encountered most of the time in zone z1 during the Sorcom series, classic seasonal variation in phytoplankton production are recovered, but with more frequent bloom in winter or autumn than in spring. This last point (i.e. the advance in the year of the "spring bloom") must be pointed out because it seems confirmed by another series (Sofcom-Somlit Insu Observation Service) developed since 1994 on a station located at the south-opening of the gulf of Marseilles and which is followed each 2 weeks by a profiling of the water layers from 0 to $60 \mathrm{~m}$.

The scope of this marine area as provided by the 5 years of the Sorcom series and its conclusions, must be limited to the surface layers. But a study of the composition of 35 sediment samples collected along the transit (Younes, 2000; Alliot et al., in press) has demonstrated that the salinity gradient and its organic matter loading charge (including chl.b and pollutants) has a clear correspondence in the enrichment of sediments between the Rhone and Marseilles. From another point of view, a precise examination of some 11 Spot-satellite views of the zone, which were captured the same day and during the same time-period (10:00 GMT) as corresponding Sorcom cruises (Younes et al., in preparation) have shown that the color of the dilution plume along the transect is well-fitted by in situ salinity records.

\section{References}

Alliot, E., Younès, W., Romano, J.-C., Rebouillon, P., Massé, H., 2003. Biogeochemical impact of a dilution plume (Rhone River) on coastal sediments. Comparison between a long-term surface water survey (1996-2000) and sediment composition. Estuar. Coast. Shelf Sci., in press.

Barale, V., 9-13 November 1999. Mediterranean coastal features from satellite observations. 99 Joint Conference, Land-Ocean Interactions: Managing Coastal Ecosystems, , Antalya, Turkey . In: Özhan,, E. (Ed.), Medcoast 99-Emecs, pp. 1899-1908.

Barale, V., Zin, I., 1997. Impact of continental margins in the Mediterranean Sea: hints from the surface colour and temperature historical record. In: Özhan,, E. (Ed.), Medcoast 97, pp. 753-766 11-14 November 1997 Qawara, Malta.

Beckers, J.M., Brasseur, P., Nihoul, J.C.J., 1997. Circulation of the western Mediterranean: from global to regional scales. Deep-Sea Res. II 44, 531-550.

Cauwet, G., Gadel, F., De Souza Sierra, M.M., Donard, O., Ewald, M., 1990. Contribution of the Rhone river to organic carbon inputs to the Northwestern Mediterranean Sea. Cont. Shelf Res. 10, 1025-1037.

Conan, P., Pujo-Pay, M., Raimbault, P., Leveau, M., 1998. Variabilité hydrologique et biologique du golfe du Lion. II. Productivité sur le bord interne du courant. Oceanol. Acta 21 (6), 767-782.

Coste, B., Raimbault, P., 1993. Recent data on the nutrient input into the Mediterranean Sea by the Rhone river. In: Martin, J.-M., Bdarth, B. (Eds.), EROS-2000. Nerc, Plymouth, UK. Water Pollut. Res. Rep., 30, pp. 47-50.

Dai, M., Martin, J.-M., Cauwet, G., 1995. The significance role of colloids in the transport and transformation of organic carbon and associated trace metals $(\mathrm{Cd}, \mathrm{Cu}$ and $\mathrm{Ni}$ ) in the Rhone delta (France). Mar. Chem. 51, $159-175$. 
Eisma, D., Bernard, P., Boon, J.J., Van Grieken, R., Kalf, J., Mook, W.G., 1985. Loss of particulate organic matter in estuaries as exemplified by the Ems and Gironde estuaries. In: Degen, E.T., Kempe, S., Herrera, R. (Eds.), Transport of Carbon and Minerals in Major World Rivers, Mitt. Geol.-Palâont. Inst. Univ. Hamb., 58, pp. 397-412.

Elliot, A.J., Hurford, N., 1989. The influence of wind and wave shear on the spreading of a plume at sea. Oil Chem. Pollut. 5, 347-363.

Lascombes, C., 1993. La pollution du Rhone: origine, nature, effets, maîtrise. Proceedings $5^{\text {e }}$ Rencontre de l'Agence Régionale pour l'Environnement (ARPE)- Provence-Alpes-Côte d'Azur. pp. 13-27.

Lefevre, D., Minas, H.J., Minas, M., Robinson, C., Le, P.J., Williams, B., Woodward, E.M.S., 1997. Review of gross community production, primary production, net community production and dark community respiration in the Gulf of Lions. Deep-Sea Res. II 44 (3-4), 801-832.

Lochet, F., Leveau, M., 1990. Transfers between an eutrophic ecosystem, the river Rhone, and an oligotrophic ecosystem, the northwestern Mediterranean Sea. Hydrobiologia 207, 95-103.

Loeillet, C., Leveau, M., 1985. Influence des apports rhodaniens sur la structure du système particulaire dans le Golfe du lion. C. R. Acad. Sci. Paris, T.301, Série II (6), 397-402.

Martin, J.-M., Saliot, A., 1991. Bilan des apports fluviatiles et atmosphériques d'éléments et composés chimiques en Méditerranée occidentale. Proceedings $3^{\mathrm{e}}$ Rencontre de l'Agence Régionale pour l'Environnement (ARPE)-Provence-Alpes-Côte d'Azur. pp. 61-66.

Millot, C., 1979. Wind induced upwellings in the Gulf of Lion. Oceanol. Acta 2, 261-274.

Millot, C., 1990. The Gulf of Lion's hydrodynamics. Cont. Shelf Res. 10, 885-894.
Pont, D., 1992. Vers une meilleure connaissance des apports du Rhône à la Méditerrannée. 2. État des connaissances, études préliminaires et méthodologie retenue. Proceedings $4^{\mathrm{e}}$ Rencontre de l'Agence Régionale pour l'Environnement (ARPE)- Provence-Alpes-Côte d'Azur. pp. 16-24.

Rohling, E.J., 1994. Review and new aspects concerning the eastern Mediterranean sapropels. Mar. Geol. 122, 1-28.

Romano, J.-C., Younes, W.A.N., Arlhac, D., Bensoussan, N., 9-13 November 1999. Influence of rivers on adjacent coastal waters: observations on the Rhone and Nile Rivers. Joint Conference, Land-Ocean Interactions: Managing Coastal Ecosystems, Antalya, Turkey. In: Özhan,, E. (Ed.), Medcoast 99-Emecs 99, pp. 19-34.

Romano, J.-C., Younes, W.A.N., 2003. A new low-coast high frequency GPS referenced recording system for monitoring coastal marine environments. J. Coast. Res., in press.

UNEP/ECE/UNIDO/FAO/UNESCO/WHO/IAEA, 1984. Pollutants from land based sources in the Mediterranean. Regional Seas Reports and Studies, 32.

Younes, W.A.N., Romano, J.-C., Arlhac, D., Bensoussan, N., 7-10 September 1999. Enregistrements périodiques 2D, à haute fréquence et à moyenne echelle d'espace comme moyen d'étude d'un hydrosystème à forte variabilité spatio-temporelle (plume de dilution du Rhône). $4^{\mathrm{e}}$ Congrès international Limnologie-Oceanographie, Talence, France.

Younes, W.A.N., 2000. Observation par une acquisition à haute definition spatiale de la variabilité temporelle à differentes echelles d'un hydrosystème estuarien, le Rhône, et de son influence sur les eaux côtières. Ph.D. Thesis. Université de la Méditerranée, pp. 237. 